\title{
PEDAGOGY
}

\section{ACMEOLOGICAL CONCEPT OF PROFESSIONAL EDUCATION DEVELOPMENT IN THE CONDITIONS OF INTEGRATION AND GLOBALIZATION OF THE EUROPEAN SPACE}

\author{
Zaiats Ruslana \\ Ukraine, Odessa, Odessa Higher Professional School of Trade and Food Technology \\ Teacher of specialized disciplines
}

DOI: https://doi.org/10.31435/rsglobal_ws/31012020/6905

\section{ARTICLE INFO}

Received: 07 November 2019

Accepted: 15 January 2020

Published: 31 January 2020

\section{KEYWORDS}

acmeological concept of development, vocational education,

personal and professional

development,

future specialists in trade and

restaurant industry,

integrated labor market.

\begin{abstract}
The preconditions for the acmeological concept of the development of vocational education in the conditions of integration and globalization of the European space are the most developed directions, which are connected with a special kind of progressive development of a mature personality - the personal and professional development of the future trade and restaurant professionals. In particular, the problem of finding and defining the laws, mechanisms, conditions and factors for the development of vocational training of students of vocational education institutions to the level of highly qualified and necessary specialist in the modern integrated labor market in the context of globalization is being updated in Europe. At the same time, there are reference models for the training of future specialists, which are a systematic factor of successful personal and professional development in the conditions of introduction of modern interactive and computer technologies.
\end{abstract}

Citation: Zaiats Ruslana. (2020) Acmeological Concept of Professional Education Development in the Conditions of Integration and Globalization of the European Space. World Science. 1(53), Vol.3. doi: 10.31435/rsglobal_ws/31012020/6905

Copyright: (C) 2020 Zaiats Ruslana. This is an open-access article distributed under the terms of the Creative Commons Attribution License (CC BY). The use, distribution or reproduction in other forums is permitted, provided the original author(s) or licensor are credited and that the original publication in this journal is cited, in accordance with accepted academic practice. No use, distribution or reproduction is permitted which does not comply with these terms.

Introduction. Scientists pay much attention to the impact of globalization and integration processes on the vocational education system in Ukraine. That globalization is a complex, objective, historical process of structural and functional changes that covers all aspects of life in general towards the universalization of the world, the adoption of common standards and models of European space. In today 's world, education has become the object of globalization; In order to meet the challenges of a globalized world, society must adapt the vocational education system to the requirements of the European space. According to the researchers, globalization in the field of vocational education contributes to the standardization of vocational training in general, under the influence of modern computer technologies, the emergence of global information and educational environments, and the main factor influencing vocational education is the economic aspect globalization as the second emphasizes the paramount importance of the market and reduce the role of the public sector. It is worthy of other scholars to judge the globalization of vocational education, its internationalization, which facilitates the free exchange of information between teachers and students of vocational education institutions, and with other educational institutions of different countries, as well as the creation of common specialized training programs, and globalization is universalization of educational planning at the expense of demand certain type of specialist s to global WMD integrated author at work.

B. Lomov, said, that "selective targets" are based on conceptual ideas about acmeological their nature and content. That is why the system of reasoned theoretical views is an important factor in the 
development of the acmeological concept of the development of vocational education of Ukraine in the conditions of integration and globalization of the European space. The concept should be generalizable and substantively represented by a system of theoretical ideas, views, on the ways and methods of development of vocational education.

Research results. In the information society vocational education dramatic changes UT its basic components, it is the organizational structure and the methods and forms of education and training, and teaching staff, etc. In this regard, distance learning via Internet is attractive and accessible, which saves time and money, and enhances the quality of vocational education through features such as self-management, scheduling flexibility, innovation, etc. These changes inevitably involve changes in the content of vocational education, in the training of professionals in the trade and restaurant industry. This technology development plays are crucial role in the further modernization of the scope of professional and technical education. Before professional education raises many questions of globalization: strategy development based on integration; international quality assurance; entrepreneurial approach to the operation of professional and technical education; information and communication and technology and virtual vocational education institutions. The advent of the latter solves the problems of equality and accessibility of vocational education.

In the context acmeological approach is considered the specifics of global $\mathrm{kg}$ esiv under the new management model, reform, restructuring and improvement of vocational education in terms of the new requirements.

Process development of vocational education should be considered a system approach, namely due to the changes and development of subsystems of vocational education, normative regulation, motivation for self-development and professional achievements of the future experts in trade and restaurant households of households, self-reflective in terms uncovering the creative and professional potential of the individual in future professionals in the trade and restaurant industry. Subsystem professionalism characterized by a harmonious combination of high professional competence and professional skills and skill level of professional training of future specialists in trade and restaurant business. The main cognitive component of the subsystem of professionalism is the professional competence of future professionals. The latter is defined as a sphere of professional conduct, a system of knowledge that is constantly expanding and enabling the pursuit of professional activity in the conditions of integration and globalization of the European space. The professional competence of future specialists is directly related to the professionalism of the individual - the sphere of management, the range of knowledge are directly related to it. By the substructure vocational education refers only part of it and that is associated with the ability to operate effectively in a professional process definition and clear outlines key elements, the choice of effective methods and techniques of students and teacher s.

General acmeological invariants of professionalism in the structure of professionalism of activity act as effective special skills to make reliable and accurate forecasts - the basis of planning and implementation, acquired in the institution of vocational education, professional skills and skills to make responsible and effective decisions, including in extreme situations and extreme situations., promptly and at a high level to find solutions to problems encountered in the process. Special acmeological invariants of professionalism can be represented as such skills, reflecting the specific professional activity of future specialists, for example, they must possess : developed communication skills to influence and persuade, defend and argue their point of view, to work in a team, to work in a team; professional knowledge, skills and abilities; the ability to self-actualize and develop throughout the professional career, etc. It is important to note that the content of the subsystem of professionalism of teachers ' activities, as the main element of students' acquisition of knowledge, skills and skills, is not a kind of "frozen" education, it implies constant enrichment, expanding the range of improvement of the system of knowledge, skills and skills. I k consequence, increases the efficiency of, and she becomes more creative and direct impact on the quality of the knowledge and skills of future specialists in trade and restaurant business. Development of the subsystem of professionalism of activity can be carried out in different ways - in the process of independent work, professional selfimprovement, advanced training, development of related professions, internships, etc.

At the All-Ukrainian level, the problem of creating conditions for the development of vocational education becomes a problem. Therefore, it is necessary to clarify trends of vocational education Ukraine in the context of globalization, aimed at improving the competitiveness of future specialists, because curriculum that determines the content and sequence of subjects in the preparation 
of future specialists on site, determine what knowledge and skills in î́è WMS ut receive during training. It is noted that the acmeological concept of the development of vocational education of Ukraine in terms of its integration into the European space requires a radical reform of the system of vocational education, in particular, bringing it in line with European requirements. Reforming the vocational education system in Ukraine should enable it to become an equal member of the European educational and scientific space, on the way to scientific, technical and social progress, which will increase the level of professionalism of future professionals in the trade and restaurant industry.

The process of modernizing the content of vocational education is based on the positive experience of European colleagues and at the same time foresees significant changes caused by current trends in social development. The new approaches provide for a qualitative update of the content of vocational education in line with the priority objectives of vocational education formulated by the European educational community. They encompass the holistic development of the individual by ensuring the growth of his or her mental, ethical, aesthetic, emotional, physical and social potential; preparing students for work, an active role in the economic and social life of society, successful activities in the face of rapid changes in technology and multicultural society; development of scientific thinking skills, critical understanding of reality and problem-solving skills.

In turn, the dissemination and implementation of modern approaches to the formation of content training future professionals. The content of education is determined by the educational and professional programs, which reflect the semantic or aspects of educational qualification characteristics defined normative content of education, set requirements for the content, scope and level of training of future specialists in trade and restaurant business.

Acmeological research emphasizes that a feature of the cognitive sphere of future specialists is the active reflection of reality and the ability to be well-guided in non-standard sittings. Thanks to productively working intelligence, teachers of vocational education institutions, in turn, are able to improve the professionalism of the personality of future professionals, due to the level of development of professionally important qualities in students of vocational education institutions, ie such personality traits that affect the performance of the activity and personality., memory, imagination, and psychological characteristics - emotional warmth, attractiveness, fatigue, tolerance, etc. In acmeological research, the role of personality strength and volitional qualities, which are the necessary conditions for achieving the set goals and the internal regulator of self-development and selfimprovement, is especially emphasized.

The development of professionally important and personal and business qualities is successfully carried out with the help of psychological and acmeological technologies. Psychological and acmeological studies show that the development of professionalism of the individual correlates with the reflexive organization of activities and the reflective culture of future professionals in the trade and restaurant industry. In general, it should be noted that measures taken at the state level have made possible further changes at other levels in the content of vocational education. A number of measures that led to changes in the content of vocational education were implemented at the level of vocational education institutions. In accordance with the requirements of the educational policy of Ukraine, there is a transition to a credit-module system of assessment of students' knowledge. $\mathrm{C}$ is going through Introductio th ICT in the learning process, which in turn allowed to introduce a number of innovations in the training of future specialists of the sphere of trade and restaurant business. In particular, this ability to use the learning process: electronic library catalogs, search engines, access to (Europe's largest educational and research network) GEANT, laboratories and to develop e lektronnyh manuals, presentations, tests; distance education and more.

Conclusions. Based on the above, the realization of this concept of development of vocational education allows future professionals in the trade and restaurant industry to reach an acmeological level, which will increase as professionalism increases.

And the impact of educational reforms on the content of the training of future professionals is reflected in the implementation of changes aimed at overcoming the defects of the existing education system and thus contribute to its adaptation to the needs of today and the professional requirements of the European space. The impact of these processes on vocational education, on the content of training future professionals is in different directions, first of all: the introduction of information and communication technologies in the educational process; approximation to the world educational standards; training courses, programs, textbooks, engaging and disseminating non-traditional forms of 
education and training, conducting classes, borrowing experience and more. In the future it is planned to make a detailed analysis of changes in the content of vocational education from the point of view of their influence on the process of training future specialists.

\section{REFERENCES}

1. Agapov VS Formation of self-concept of personality: theory and practice. - M.: Inst. Of Youth, 1999

2. Bodalev AA Vershin in adult development: characteristics and conditions of achievement. - M.: Flint Science, 1998.

3. Higher Education and the Bologna Process: Educ. tool. for students. higher. teach. closed / Dmitrychenko MF, Khoroshun BI, Yazvinskaya OM, Danchuk VD - K.: Knowledge of Ukraine, 2007. - 440 p.

4. Higher education in Ukraine and the Bologna process: Educ. manual / Edited VG Kremin; MF Stepko, Ya. E. Bolyubash, VD Shinkaruk, VV Grubiyanko, II Babin. - Ternopil: The Educational Book - Bogdan, 2004. - 384 p.

5. Volkova NP Pedagogy: study. tool. / NP Volkova. - The 4 types, p. - K.: Akademvidav, 2012. - 616 p.

6. Debich M. Evolution of higher education at the turn of the century and prospects for its development / M. Debich // Higher education of Ukraine. - 2013. - № 4. - P. 107-113.

7. Zinchenko VV Sociosystemic globalization of higher education: trends. consequences, prospects / VV Zinchenko // Educational discourse. - 2015. - № 3 (11). - pp. 127-137.

8. Kuzmina NV Professionalism of personality of teacher and master of industrial training. - M.: Higher School, 1998.

9. Markova A.K. Psychology of professionalism. - M.: Knowledge, 1996. 